RHODORA, Vol. 119, No. 978, pp. 110-131, 2017

(C) Copyright 2017 by the New England Botanical Club

doi: 10.3119/16-22; first published on-line June 9, 2017.

\title{
THE ALPINE VASCULAR PLANTS OF BAXTER STATE PARK, MAINE, USA
}

\author{
Abigail J. Urban \\ College of the Atlantic, 105 Eden Street, Bar Harbor, ME 04609
}

\section{Glen H. Mittelhauser}

Maine Natural History Observatory 317 Guzzle Rd., Gouldsboro, ME 04607 Author for correspondence; email: purplesandpiper@gmail.com

\section{MatThew Dickinson}

P.O. Box 571, Cape Neddick, ME 03902

\section{Nishanta RaJakaruna}

Biological Sciences Department, California Polytechnic State University, San Luis Obispo, CA 93407

and

Unit for Environmental Sciences and Management, North-West University, Private Bag X6001, Potchefstroom, 2520, South Africa

ABSTRACT. We conducted 12 days of field surveys on five mountains over $1100 \mathrm{~m}$ in elevation (Katahdin, North Brother, South Brother, Mount Coe, and The Owl) in Baxter State Park (BSP), Maine during the summers of 2013-14. In addition, we examined historic manuscripts, unpublished data, and herbarium records for plant records from the five mountains. Katahdin, the largest and tallest of the five mountains, has a rich history of botanical exploration and we documented 1559 herbarium vouchers that were collected from the mountain, primarily before the mid-1900s. Combining all data sources, we documented 38 families, 87 genera, and 131 taxa of vascular plants growing on our five study mountains above $1100 \mathrm{~m}$ in elevation from the 1800 s to the present. This includes 28 taxa historically documented in the study area but not observed since 1980 at over $1100 \mathrm{~m}$. In our study area, we found 16 taxa listed as endangered in Maine, 16 taxa listed as threatened, 10 taxa listed as of special concern, and five taxa considered possibly extirpated. This work provides a reference for future monitoring and plant conservation efforts within BSP and alpine habitats in Maine.

Key Words: Alpine plants, Baxter State Park, climate change, Katahdin, Piscataquis County flora, rare species 


\section{INTRODUCTION}

Alpine plants are especially adapted to the challenges inherent in growing in high altitudes, including short growing seasons, severe winter temperatures, extreme annual climatic fluctuations, wind, blowing snow, and ice (Breen et al. 2014; Körner 2003). An important factor in their ability to survive such harsh conditions includes a system of mutualism, interdependence, and facilitative interactions among plants and other biota within alpine areas (Choler et al. 2001). Although alpine habitats account for only 3\% of all land area, they contain $4 \%$ of all flowering plant species on the planet (Spehn and Körner 2005). In Maine, alpine tundra occurs above $1100 \mathrm{~m}$ in elevation (Cogbill and White 1991) although alpine areas can occur at lower elevations. Such areas in New England support 48 globally or regionally rare plant species (New England Wild Flower Society 2015).

Baxter State Park (BSP), located in northern Maine, consists of approximately 81,000 hectares (ha), including the largest expanse of alpine habitat found in the state. Forty-five mountains occur within BSP and six of these are over $1100 \mathrm{~m}$ in height and include alpine habitat. The alpine summits of BSP, particularly Katahdin, have a long and rich history of botanical exploration that began in the 1800s and continued into the early 1900s (Fernald 1901). These early botanical explorations, focusing on Katahdin, include the work of Bailey (1837), Lamson-Scribner (1892), Churchill (1901), Fernald (1901), Williams (1901), Harshberger (1902), Harvey (1903a, b; 1909), Norton (1924, 1935), Blake (1926a, b), Thurber (1926), Laski (1927), Stebbins (1927, 1929), Ewer (1930), Dyer (1942), and Allard and Leonard (1945). The first park-wide survey of alpine vegetation was conducted in the early 1980s, resulting in lists of alpine species from many summits (Hudson 1985). Since the 1980s, much of the botanical survey work in alpine areas of the park has consisted of verifying known rare plant populations on Katahdin (Dibble et al. 1990), including focused surveys at specific study sites (Cogbill and Hudson 1990; Clark 1999), surveys by the Maine Natural Areas Program, two multi-day group forays in 2000 and 2010 sponsored by the Maine Task Force of the New England Plant Conservation Program, and incidental plant observations by knowledgeable people hiking in the area. Katahdin, the tallest mountain in Maine, and the surrounding peaks harbor more state-listed rare, threatened, and endangered plant species than any other location in Maine (D. Cameron, Maine Natural Areas Program, pers. comm.). In addition to the rare plant surveys, there have been explorations of alpine lichens and bryophytes (Dibble et al. 2009; Fryday 2006; Hinds et al. 2009; Miller 2009; Miller et al. 2005). 
Despite the number of historical surveys, there has been no list of alpine plants for BSP that incorporates all historic research and collections, including recent field surveys. The goal of this study was to compile a baseline list of vascular plants for the alpine zones of five mountains over $1100 \mathrm{~m}$ in elevation (Katahdin, North Brother, South Brother, Mount Coe, and The Owl) within BSP by cross-referencing herbarium vouchers, published and unpublished reports, and field work conducted during June-September 2013 and 2014.

\section{MATERIALS AND METHODS}

Our research focused on five mountains over $1100 \mathrm{~m}$ in elevation in BSP, Maine: Katahdin 1606 m, North Brother 1265 m, South Brother $1210 \mathrm{~m}$, Mount Coe $1157 \mathrm{~m}$, and The Owl $1139 \mathrm{~m}$ (Figure 1). These granite mountains formed about 400 million years ago during the Acadian orogeny (Caldwell 1972). We built a cross-referenced database of alpine plant species based on recent field efforts, compilations of published and unpublished historical manuscripts and records, and examination of herbarium vouchers. We recorded taxa that occurred in alpine zones above $1100 \mathrm{~m}$ in elevation. For each taxon documented from our study mountains, we determined if it was found above $1100 \mathrm{~m}$ in elevation using elevation details noted on voucher labels, place names of known elevation, georeferenced coordinates, and our field work. Voucher collections from 1900 onwards often gave specific details on the location where a specimen was collected, and these details were extremely useful for building the list of alpine plants.

We examined the following historic manuscripts: Bailey (1837), Lamson-Scribner (1892), Churchill (1901), Fernald (1901), Williams (1901), Harshberger (1902), Harvey (1903a, b; 1909), Norton (1924, 1935), Blake (1926a, b), Thurber (1926), Laski (1927), Stebbins (1927, 1929), Ewer (1930), Dyer (1942), Allard and Leonard (1945), Hudson (1985), Cogbill and Hudson (1990), Dibble et al. (1990), and Clark (1999). To locate historical herbarium vouchers, we visited or examined voucher databases at Arnold Arboretum (АAH), E. C. Smith Herbarium (ACAD), Charles B. Graves Herbarium (CCNL), George Safford Torrey Herbarium (CONN), Gray Herbarium (GH), George R. Cooley Herbarium (GRCH), College of the Atlantic Herbarium (HCOA), University of Maine Herbarium (MAINE), New England Botanical Club Herbarium (NEBC), Albion R. Hodgdon Herbarium (NHA), William and Lynda Steere Herbarium (NY), Pringle Herbarium (vT), and Yale University Herbarium (YU). We conducted 10 days of research at NEBC, GH, and AAH and examined collections of alpine taxa from northeastern North 


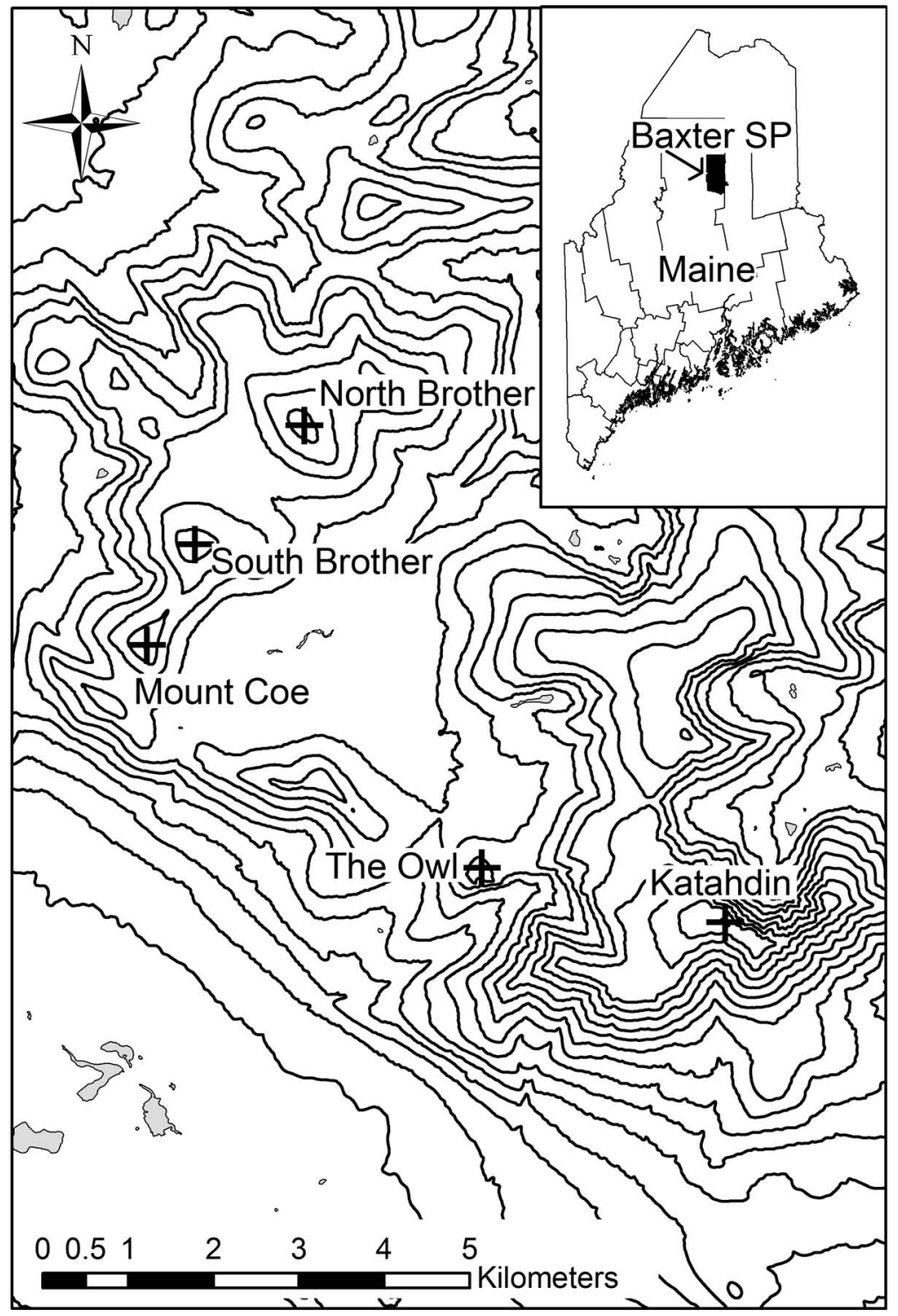

Figure 1. The five study mountains in the southern portion of Baxter State Park, Maine. Contour lines represent $75 \mathrm{~m}$ elevation intervals. 
America. The alpine taxa search list for herbarium research was compiled from the list of taxa reported in regional alpine guides (Appalachian Mountain Club 1964; Jones and Willey 2012).

We conducted 13 days of field surveys on our study mountains during the summers of 2013 and 2014. Our dates of field work on each mountain were as follows: Katahdin on 24 August 2013, 29 September 2013, and 9-12 and 21 June 2014; North Brother on 5 August 2013 and 24 June 2014; South Brother on 5 August 2013 and 27 June 2014; Mount Coe on 27 June 2014; and The Owl on 22 June 2013. Fort Mountain, at $1179 \mathrm{~m}$, is also an alpine summit in BSP, however, we were not able to visit this mountain due to challenging field conditions. We conducted multiple surveys on Katahdin because of its large area of alpine habitat (including Baxter and Pamola Peaks, Hamlin Ridge, and the Tablelands) and known diversity of rare plant species. Surveys were conducted both on- and off-trail on each mountain, and numerous photographs were taken to serve as vouchers for our findings. Photographic vouchers from this study are archived at Maine Natural History Observatory, Gouldsboro, ME. Nomenclature and authorities follow Haines (2011). We follow Maine rarity rankings developed by the Maine Natural Areas Program (2016).

We selected $>1100 \mathrm{~m}$ as our criterion for defining the alpine zone within BSP. Treeline is generally a reliable guide to distinguish the lower limits of alpine habitat, however, the timberline in some areas including BSP is too indistinct (Billings 1974; Billings and Mooney 1968). In BSP, treeline occurs between 980 and $1130 \mathrm{~m}$ (Hudson 1985) and alpine tundra occurs above $1100 \mathrm{~m}$ (Cogbill and White 1991).

\section{RESULTS}

We documented 1559 herbarium specimens collected from alpine and subalpine areas on our study mountains in BSP, Maine. All of these herbarium vouchers were from Katahdin, except two specimens that were collected from Mount Coe by C. D. Richards in 1955 and two specimens collected from South Brother by F. Steele in 1965. Table 1 lists the major collectors on Katahdin and the years their specimens were collected. Collecting voucher specimens since the establishment of BSP has been strictly regulated, which explains the decline of vouchers after the mid-1900s.

Overall, through the herbarium and literature research and field surveys, we documented 38 families, 87 genera, and 131 taxa of vascular plants growing on our study mountains above $1100 \mathrm{~m}$ from the 1800s to the present (Appendix). This includes 28 taxa for which we 
Table 1. Researchers who collected more than 25 herbarium vouchers on Katahdin in Baxter State Park, Maine. Baxter State Park stipulated that we limit collections of plants during our field work, and no collections were allowed in alpine areas, thus no herbarium vouchers were taken from alpine areas during this study.

\begin{tabular}{lcc}
\hline Researcher & Years of Collections & Number of Vouchers \\
\hline G. Thurber & $1847-1899$ & 44 \\
F. Scribner & $1873-1874$ & 37 \\
F. Briggs & $1891-1892$ & 83 \\
E. Merrill & 1898 & 38 \\
M. Fernald & 1900 & 314 \\
E. Williams & 1900 & 134 \\
J. Churchill & 1900 & 54 \\
A. Norton & $1923-1936$ & 52 \\
S. Ewer & $1928-1930$ & 137 \\
F. Steinmetz & $1930-1940$ & 49 \\
E. Walker & 1934 & 35 \\
G. Torrey & 1940 & 47 \\
G. Rossbach & $1948-1975$ & 52 \\
C. Richards & $1953-1955$ & 72 \\
\hline
\end{tabular}

found no herbarium vouchers collected above $1100 \mathrm{~m}$; of these, all had vouchers from lower elevations (between 750-1100 $\mathrm{m}$ ) on the mountains except Calamagrostis stricta subsp. inexpansa, Euphrasia oakesii, Nabalus altissimus, and Rhinanthus minor subsp. groenlandicus. The most species-rich plant families encountered were Ericaceae (17 taxa), Poaceae (14 taxa), and Cyperaceae (13 taxa).

Of the 131 taxa documented, only twelve species occurred on all our study summits: Abies balsamea, Betula cordifolia, Carex bigelowii subsp. bigelowii, Chamaepericlymenum canadense, Empetrum nigrum, Juncus trifidus, Picea mariana, Rhododendron groenlandicum, Vaccinium angustifolium, V. myrtilloides, V. uliginosum, and V. vitis-idaea subsp. minus. A total of 28 taxa were historically documented in the study area but have not been re-located above $1100 \mathrm{~m}$ elevation since 1980: Andromeda polifolia var. glaucophylla, Calamagrostis pickeringii, Carex communis var. communis, C. flava, C. leptalea subsp. leptalea, C. rariflora, Cinna latifolia, Danthonia spicata, Epilobium lactiflorum, Euphrasia oakesii, Fragaria virginiana subsp. virginiana, Galium kamtschaticum, Lycopodium lagopus, Maianthemum racemosum subsp. racemosum, Neottia cordata, Osmunda claytoniana, Picea glauca, Platanthera dilatata var. dilatata, Rhinanthus minor subsp. groenlandicus, Salix argyrocarpa, Sambucus racemosa, Saxifraga paniculata subsp. neogaea, Silene acaulis, Stellaria borealis subsp. borealis, 
Symphyotrichum puniceum var. puniceum, Trisetum spicatum, Viola palustris var. palustris, and $V$. selkirkii.

We also documented 16 state endangered species (Betula glandulosa, B. minor, Bistorta vivipara, Calamgrostis stricta subsp. inexpansa, Cardamine bellidifolia var. bellidifolia, Epilobium anagallidifolium, E. hornemannii subsp. hornemannii, Festuca prolifera, Luzula confusa, Micranthes foliolosa, Nabalus bootii, Omalotheca supina, Poa laxa subsp. fernaldiana, Salix arctophila, Saxifraga paniculata subsp. neogaea, and Vahlodea atropurpurea), 16 state threatened species (Agrostis mertensii, Anthoxanthum monticola subsp. monticola, Arctous alpina, Arnica lanceolata subsp. lanceolata, Calamagrostis pickeringii, Diphasiastrum sitchense, Harrimanella hypnoides (Figure 2a), Kalmia procumbens (Figure 2b), Luzula spicata, Phleum alpinum, Phyllodoce caerulea (Figure 2c), Rhododendron lapponicum (Figure 2d), Salix herbacea, S. planifolia subsp. planifolia, S. uva-ursi, and Solidago leiocarpa), ten species of special concern (Carex atrataformis, $C$. bigelowii subsp. bigelowii, C. scirpoidea subsp. scirpoidea, Castilleja septentrionalis, Diapensia lapponica subsp. lapponica, Galium kamtschaticum, Geocaulon lividum, Huperzia appressa, Minuartia groenlandica, and Vaccinium boreale), and five species that are considered possibly extirpated from Maine (Carex rariflora, Epilobium lactiflorum, Euphrasia oakesii, Salix argyrocarpa, and Silene acaulis); Appendix 1. All state endangered and threatened taxa were reported from Katahdin but only four rare taxa were found on other study summits (Agrostis mertensii on Mount Coe and The Owl, Anthoxanthum monticola subsp. monticola on The Owl, Arctous alpina on North Brother, and Solidago leiocarpa on The Owl).

\section{DISCUSSION}

We compiled a list of 131 taxa of alpine vascular plants growing on five study mountains in BSP above $1100 \mathrm{~m}$ in elevation from the $1800 \mathrm{~s}$ to the present based on an assessment of herbarium vouchers, published and unpublished reports, and recent field work. Katahdin, the most botanically diverse summit studied in BSP, possesses an expanse of alpine habitat and micro-climates including ridgelines, cols, slides, three summits, as well as a flat plateau contributing to habitat heterogeneity, floristic diversity, and creating an array of contrasting species within relatively short distances (Fernald 1901).

This work synthesizes the historic and recent observations of vascular plants for the alpine areas of BSP, but our knowledge of the distribution and status of alpine plants in this region remains outdated. 

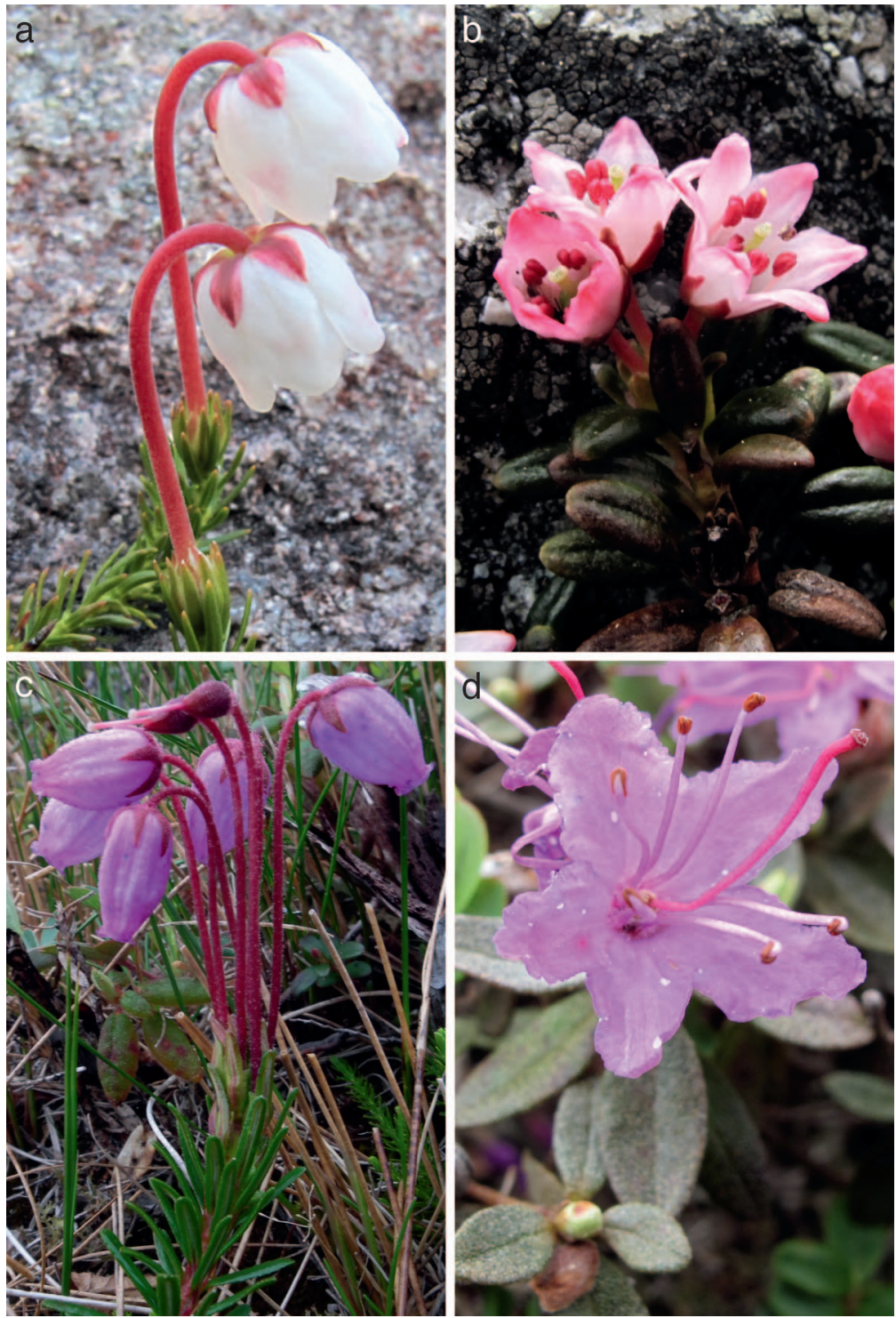

Figure 2. Four state-threatened alpine plants documented on Katahdin in Baxter State Park, Maine. A. Harrimanella hypnoides (L.) Coville; B. Kalmia procumbens (L.) Gift, Kron, \& P.F. Stevens ex Galasso, Banfi, \& F. Conti; C. Phyllodoce caerulea (L.) Bab.; D. Rhododendron lapponicum (L.) Wahlenb. 
We documented over 1500 herbarium collections from Katahdin alone with most of these collections occurring before the mid-1900s, and we cannot rule out overzealous collecting contributing to the decline or extirpation of some taxa. Our list included 28 taxa historically documented from the study area but not observed since 1980, but few field surveys have been conducted looking for these missing taxa. Fernald (1901), writing over 100 years ago, mentioned the incomplete botanical data of the Katahdin region and the need for more thorough research, noting that "many who have written of the mountain seem to have noticed only a few common species." Allard and Leonard (1945) mentioned that an extensive and in-depth study of the plant composition on Katahdin will take years and the efforts of "many intrepid botanists" before a complete snapshot of alpine species within BSP can be understood. In 1903, Harvey (1903a) noted that the North Basin of Katahdin was the least explored area of the mountain and, even in 2016, this is still the case.

The identification of some taxa historically reported from Katahdin remains undetermined while others were misidentified. For example, Viola palustris var. palustris was historically reported from Katahdin (Fernald 1901), although many of the lower elevation herbarium vouchers were later annotated to $V$. pallens based on the white flower color and other characteristics (Haines 2011). For all historic alpine vouchers of $V$. palustris, flower color is not noted and fruits, needed to confirm identification, were not found on specimens. In addition, Calamagrostis canadensis var. langsdorfii collections by J.R. Churchill and M.L. Fernald in the north basin of Katahdin were all annotated to C. canadensis var. canadensis. Also, all vouchers originally labeled as Lycopodium selago ( $=$ Huperzia selago) were later annotated to either Huperzia $\times$ josephbeiteli or $H$. appressa.

Alpine habitats are experiencing abiotic and biotic stressors (Klanderud and Totland 2005), and the need for baseline data and monitoring efforts in these habitats is high (Capers and Slack 2016). The effects of climate change on the alpine flora in BSP are difficult to discern because the climate influences on alpine plants in general, are not fully understood (Cannone and Pignatti 2014; Rammig et al. 2010; Theurillat and Guisan 2001). Species with narrow ranges, small population sizes, and a distribution determined by low temperatures may be more susceptible to climate change (Capers and Stone 2011; Lesica and McCune 2004; Pauli et al. 2015; Sætersdal and Birks 1997), resulting from reduced habitat via altitudinal shifts of lowland species (Walker et al. 2006), decreased snow deposition, and changes in precipitation and wind frequency (Kimball and Weihrauch 2000). 
Conversely, there are also studies that suggest that alpine zones will provide a refuge for alpine taxa and preserve species diversity despite climatic changes (Pepin 2000; Ryerson 1990; Seidel et al. 2009). It is thought that, because alpine species are slow growing, the impacts of climate change will not be as initially dramatic as for species at lower elevations (Cannone et al. 2007; Neilson 1993).

Perhaps the most relevant study of Maine alpine habitats in which impacts of climate change were examined was a study conducted by Capers and Stone (2011). This study examined how species composition changed over time on Bigelow Mountain, located in western Maine, and found that overall species richness increased in alpine zones due to the addition of subalpine species establishing in the alpine zone and these findings are consistent with changes observed in tundra habitats (Capers and Stone 2011). Throughout the course of the study, the dominant tree species became more frequent but there was not a significant decrease in arctic species. It is predicted that rising temperatures may have a varying impact, depending on the exposure of the site and on the boundaries of treeline (Kimball and Weihrauch 2000), and that populations of alpine species may decrease as Abies balsamea and Picea mariana encroach upon alpine habitat (Bailey et al. 2015).

Recent field survey efforts throughout BSP (Mittelhauser et al. 2016) have resulted in increased knowledge on the status and distribution of species within the park, including taxa documented from lower elevations on our study mountains. We strongly emphasize the need for additional alpine plant work, particularly on Katahdin, methodically sampling the abundance and distribution of species (Capers et al. 2013; Pauli et al. 2015). Without knowing the composition of species within the park and in fragile alpine areas, little action can be taken to combat the impacts of increased visitor disturbance and the effects of climate change. The mountains of BSP are home to a remarkably diverse array of rare alpine species and with unprecedented climatic changes predicted, a deeper understanding of alpine species is desperately needed.

ACKNOWLEDGMENTS. We thank Jean Hoekwater for arranging accommodations within the park during our research, Jensen Bissell for permission to conduct our research, and the numerous other staff at Baxter State Park for making this research possible. We thank the following organizations and foundations who helped to fund portions of our research: Baxter State Park, Friends of Baxter State Park, Maine Natural History Observatory, Maine Outdoor Heritage Fund, Nor- 
cross Wildlife Foundation, and The Waterman Fund. We also thank Maine Natural Areas Program for providing unpublished data and other technical research materials. We appreciate the warm welcome we received during our research at the herbaria we visited and we are particularly grateful to Michaela Schmull and Emily Wood at Harvard University Herbaria for their welcome during our extended research. We are grateful to our exceptional intern on this project, Jordan Chalfant, who assisted with field work. We also thank the numerous volunteers for their assistance in the field, in herbaria, and in tracking taxonomy in historic manuscripts. This manuscript was improved by the helpful comments of Jean Hoekwater, Jensen Bissell, Don Cameron, Robert Capers, and two anonymous reviewers.

\section{LITERATURE CITED}

Allard, H. A. and E. C. Leonard. 1945. Plants collected on and around Mount Katahdin in Maine. Castanea 10: 46-53.

Appalachian Mountain Club. 1964. Mountain Flowers of New England. Appalachian Mountain Club, Boston, MA.

Bailey, J. W. 1837. Account of an excursion to Mount Katahdin, in Maine. Amer. J. Sci. 32: 20-34.

Bailey, S. W., J. Hoy, And C. V. Cogbill. 2015. Vascular flora and geoecology of Mont de la Table, Gaspésie, Québec. Rhodora 117: 1-40.

Billings, W. D. 1974. Adaptations and origins of alpine plants. Arctic Antarc. Alpine Res. 6: 129-142.

- AND H. A. Mooney. 1968. The ecology of arctic and alpine plants. Biol. Rev. 43: 481-529.

Blake, J. 1926a. An excursion to Mount Katahdin. Maine Naturalist (Knox Acad.) 6: 71-73.

- 1926b. A second excursion to Mount Katahdin. Maine Naturalist (Knox Acad.) 6: 74-83.

Breen, A. L., D. F. Murray, M. K. Raynolds, I. Timling, and D. A. Walker. 2014. Ecology and evolution of plants in arctic and alpine environments, pp. 149-177. In: N. Rajakaruna, R. S. Boyd, and T. B. Harris, eds. Plant Ecology and Evolution in Harsh Environments. Nova Science Publishers, New York, NY.

Caldwell, D. W. 1972. The Geology of Baxter State Park and Mt. Katahdin. Bulletin 12. Maine Geological Survey, Augusta, ME.

Cannone, N. and S. Pignatti. 2014. Ecological responses of plant species and communities to climate warming: upward shift or range filling process? Climatic Change 123: 201-214.

- S. Sgorbati, and M. Gugleilmin. 2007. Unexpected impacts of climate change on alpine vegetation. Frontiers Ecol. Environm. 5: 360-364.

Capers, R. S. and A. D. Stone. 2011. After 33 years, trees more frequent and shrubs more abundant in northeast U.S. alpine community. Arctic Antarc. Alpine Res. 43: 49-502. 
K. D. Kimball, K. P. McFarland, M. T. Jones, A. H. Lloyd, J. S. Munroe, et AL. 2013. Establishing alpine research priorities in northeastern North America. N. E. Naturalist 20: 559-577.

- AND N. G. SLACK. 2016. A baseline study of alpine snowbed and rill communities on Mount Washington, N.H. Rhodora 118: 345-381.

Choler, P., R. Michalet, and R. M. Callaway. 2001. Facilitation and competition on gradients in alpine plant communities. Ecology 82: 32953308 .

Churchill, J. R. 1901. A botanical excursion to Mount Katahdin. Rhodora 3: $147-160$.

Clark, D. L. 1999. Alpine flora of two study sites on Mount Katahdin Maine. M.Sc. thesis, University of Maine, Orono, ME.

Cogbill, C. V. ANd W. D. Hudson JR. 1990. The baseline characterization of the alpine area of Katahdin. Unpublished report to Baxter State Park, Millinocket, ME.

- AND P. S. White. 1991. The latitude-elevation relationship for spruce-fir forest and treeline along the Appalachian Mountain chain. Vegetatio 94: $153-175$.

Dibble, A. C., N. G. Miller, J. W. Hinds, and A. M. Fryday. 2009. Lichens and bryophytes of the alpine and subalpine zones of Katahdin, Maine, I: overview, ecology, climate and conservation aspects. Bryologist 112: 651672.

, S. C. Rooney, H. Hinds, W. D. Hudson, and B. A. Sorrie. 1990. Rediscovery of some rare plants on Mt. Katahdin. Rhodora 92: 38-41.

Dyer, H. J. 1942. Distribution of woody plants on Mount Katahdin: botany problem, course 200-106. Unpublished report to University of Maine [University of Maine Special Collections], Orono, ME.

Ewer, J. 1930. Notes on Katahdin plants. Rhodora 32: 259-261.

Fernald, M. L. 1901. The vascular plants of Mount Katahdin. Rhodora 3: $166-177$.

Fryday, A. M. 2006. New and interesting North American lichen records from the alpine and sub-alpine zones of Mt. Katahdin, Maine. Bryologist 109: $570-578$.

Haines, A. 2011. Flora Novae Angliae: A Manual for the Identification of Native and Naturalized Higher Vascular Plants of New England. New England Wildflower Society, Framingham, MA.

Harshberger, J. W. 1902. A botanical ascent of Mount Ktaadn, ME. Pl. World 5: 21-28.

Harvey, L. H. 1903a. An ecological excursion to Mount Ktaadn. Rhodora 5: $41-52$.

- 1903b. A study of the physiographic ecology of Mount Ktaadn, Maine: University of Maine studies number 5. Unpublished report to University of Maine [University of Maine Special Collections], Orono, ME.

1909. The floristic composition of the vascular flora of Mount Ktaadn, Maine. Rep. (Annual) Michigan Acad. Sci. 11: 37-47.

Hinds, J. W., A. M. Fryday, AND A. C. Dibble. 2009. Lichens and bryophytes 
of the alpine and subalpine zones on Katahdin, Maine, II: lichens. Bryologist 112: 673-703.

Hudson, W. D., JR. 1985. Old-growth forests, subalpine forest, and alpine areas in Baxter State Park. Critical Areas Program Misc. Report 31, Maine State Planning Office, Augusta, ME.

Jones, M. T. And L. L. Willey. 2012. Eastern Alpine Guide: Natural History and Conservation of Mountain Tundra East of the Rockies. Beyond Ktaadn, New Salem, MA.

Kimball, K. D. and D. M. Weinrauch. 2000. Alpine vegetation communities and the alpine-treeline ecotone boundary in New England as biomonitors for climate change, pp. 93-101. In: S. F. McCool, D. N. Cole, W. T. Borrie, and J. O'Loughlin, eds., Wilderness Science in a Time of Change. Vol. 3. Wilderness as a Place for Scientific Inquiry. Proceedings RMRS-P15-VOL-3. USDA, Forest Service, Rocky Mountain Research Station, Ogden, UT.

Klanderud, K. And Ø. Totland. 2005. Simulated climate change altered dominance hierarchies and diversity of an alpine biodiversity hotspot. Ecology 86: 2047-2054.

KÖRnER, C. 2003. Alpine Plant Life: Functional Plant Ecology of High Mountain Ecosystems. Springer, The Netherlands.

Lamson-Scribner, F. 1892. Mt. Kataadn and its flora. Bot. Gaz. 17: 46-54.

LASKI, J. K. 1927. Dr. Young's botanical expedition to Mount Katahdin. Maine Naturalist (Knox Acad.) 1927: 38-62.

Lesica, P. And B. McCune. 2004. Decline of arctic-alpine plants at the southern margin of their range following a decade of climatic warming. J. Veg. Sci. 15: 679-690.

Maine Natural Areas Program. 2016. Elements of natural diversity: rare, threatened, and endangered plants. Department of Conservation, Augusta, ME. Website (http://maine.gov/dacf/mnap/features/rare_ plants/index.htm). Accessed 28 June 2016.

MilLer, N. G. 2009. Lichens and bryophytes of the alpine and subalpine zones of Katahdin, Maine, III: bryophytes. Bryologist. 112: 704-748.

A. M. Fryday, AND J. W. Hinds. 2005. Bryophytes and lichens of a calcium-rich spring seep isolated on the granitic terrain of Mt. Katahdin, Maine, U.S.A. Rhodora 107: 339-358.

Mittelhauser, G. H., J. Bissell, D. Cameron, A. C. Dibble, A. Haines, J. Hoekwater, M. Lovit, and A. Megquier. 2016. The Plants of Baxter State Park. University of Maine Press, Orono, ME.

Neilson, R. P. 1993. Transient ecotone response to climatic change: Some conceptual and modelling approaches. Ecol. Applic. 3: 385-95.

New England Wild Flower Society. 2015. State of the Plants: Challenges and Opportunities for Conserving New England's Native Flora. Framingham, MA.

Norton, A. H. 1924. Some of the more conspicuous plants of Mount Ktaadn. Maine Naturalist (Knox Acad.) 4: 77-82. . 1935. Plants apparently new to Mount Katahdin. Rhodora 37: 455. 
Pauli, H., M. Gottfried, A. Lamprecht, S. Niessner, S. Rumpf, M. Winkler, K. Steinbauer, and G. Grabherr. 2015. The GlORiA field manual standard multi-summit approach, supplementary methods and extra approaches, $5^{\text {th }}$ ed. GLORIA-Coordination, Austrian Academy of Sciences \& University of Natural Resources and Life Sciences, Vienna.

Pepin, N. 2000. Twentieth-century change in the climate record for the Front Range, Colorado, U.S.A. Arctic Antarc. Alpine Res. 32: 135-146.

Rammig, A., T. Jonas, N. E. Zimmermann, and C. Rixen. 2010. Changes in alpine plant growth under future climate conditions. Biogeosciences 7 : 2013-2024.

Ryerson, C. C. 1990. Atmospheric icing rates with elevation on northern New England mountains, U.S.A. Arctic Alpine Res. 22: 90-97.

SÆTERSDAL, M. AND H. J. B. Birks. 1997. A comparative ecological study of Norwegian mountain plants in relation to possible future climatic change. J. Biogeogr. 24: 127-152.

Seidel, T. M., D. M. Weinrauch, K. D. Kimball, A. A. P. Pszenny, R. Soboleski, E. Crete, and G. Murray. 2009. Evidence of climate change declines with elevation based on temperature and snow records from 1930s to 2006 on Mount Washington, New Hampshire, U.S.A. Arctic Antarc. Alpine Res. 41: 362-372.

Spehn, E. M. and L. C. Körner. 2005. A global assessment of mountain biodiversity and its function, pp. 393-400. In: U. M. Huber, H. K. M. Bugmann, and M. A. Reasoner, eds., Global Change and Mountain Regions, an Overview of Current Knowledge. Springer, The Netherlands.

Stebins, G. L., JR. 1927. Two plants new to Mt. Katahdin. Rhodora 29: 15-16. . 1929. Some interesting plants from Mt. Katahdin. Rhodora 31: 142143.

Theurillat, J.-P. And A. Guisan. 2001. Potential impact of climate change on vegetation in the European Alps: A review. Clim. Change 50: 77-109.

Thurber, G. 1926. Notes of an excursion to Mount Katahdin. Maine Naturalist (Knox Acad.) 6: 134-151.

Walker, M. D., C. H. Wahren, R. D. Hollister, G. H. R. Henry, L. E. Ahlquist, J. M. Alatalo, et Al. 2006. Plant community responses to experimental warming across the tundra biome. Proc. Natl. Acad. Sci. U.S.A. 103: 1342-1346.

Williams, E. F. 1901. A comparison of the floras of Mt. Washington and Mt. Katahdin. Rhodora 3: 160-165.

\section{APPENDIX}

\section{ALPINE VASCULAR FLORA OF FIVE MOUNTAINS IN BAXTER STATE PARK, MAINE}

The list of alpine vascular flora includes the vascular plants documented from above $1100 \mathrm{~m}$ elevation on Katahdin, North Brother, South Brother, Mount Coe, and The Owl, in Baxter State Park, Maine (ME). The sequence of 
families is alphabetical; within families, taxa are also listed alphabetically. Nomenclature follows Haines (2011). Species considered rare in ME are noted with the state rank: $\mathrm{S} 1$ = critically imperiled because of extreme rarity (five or fewer occurrences in ME); S2 = imperiled because of rarity (6-20 occurrences in $\mathrm{ME}) ; \mathrm{S} 3=$ rare (20-100 occurrences in ME; $\mathrm{SH}=$ occurred historically in Maine and not known to be extirpated; and SX = apparently extirpated in Maine. All endangered and threatened species are ranked S1 or S2. Abundance estimates for each species observed on our study mountains since 1980 are based on population size and distribution in which the taxon occurs on all alpine mountains in Baxter State Park, defined as follows: Common = taxa that are widespread and occurring in large numbers; Occasional $=$ species that are sporadic or scattered; Uncommon $=$ species that occur infrequently; Rare $=$ species usually restricted to small areas, specialized habitats, or consisting of one or a few populations. Taxa not observed on any of our study mountains since 1980 but listed in historic publications or noted from herbarium vouchers are flagged as historic records. The most reliably identified voucher, collected in alpine habitat, is cited for each species. For each voucher, we present collector, collection number, date of collection, and herbarium acronym. If vouchers were not located, we present citation or observation details.

\section{ADOXACEAE}

Sambucus racemosa L. - Historic (1900); Katahdin (M. L. Fernald, s.n., 11 July 1900, NEBC).

Viburnum nudum L. var. cassinoides (L.) Torr. \& Gray - Uncommon; Katahdin (Fernald 1901).

\section{APIACEAE}

Heracleum maximum Bartr. - Rare; Katahdin (Fernald 1901).

\section{ASTERACEAE}

Arnica lanceolata Nutt. subsp. lanceolata - Rare, S2; Katahdin (M. L. Fernald, s.n., 13 July 1900, GH).

Doellingeria umbellata (P. Mill.) Nees var. umbellata - Rare; Katahdin (M.

L. Fernald, s.n., 14 July 1900, NEBC).

Eurybia radula (Ait.) Nesom - Uncommon; Katahdin (M. L. Fernald, s.n., 14 July 1900, NEBC).

Nabalus altissimus (L.) Hook. - Rare; Katahdin (Cogbill and Hudson 1990).

Nabalus boottii DC. - Rare, S1; Katahdin (A. Young, Jr., s.n., August 1847, $\mathrm{GH})$.

Nabalus trifoliolatus Cass. - Uncommon; Katahdin (G. S. Torrey and J. W. Torrey, 3674, 24 August 1940, CONN).

Oclemena acuminata (Michx.) Nesom - Uncommon; Katahdin (M. L. Fernald, s.n., 13 July 1900, NEBC).

Omalotheca supina (L.) DC. - Rare, S1; Katahdin (S. J. Ewer, s.n., 1 August 1929, NEBC).

Solidago leiocarpa DC. - Uncommon, S1; Katahdin (M. L. Fernald, s.n., 14 July 1900, NEBC); The Owl (A. J. Urban, 22 June 2013, pers. obs.). 
Solidago macrophylla Pursh - Occasional; Katahdin (F. Steele, s.n., 10 August 1965, NHA).

Symphyotrichum puniceum (L.) A. \& D. Löve var. puniceum - Historic (1965); Katahdin (F. Steele, s.n., 12 August 1965, NHA).

BETULACEAE

Alnus viridis (Vill.) Lam. \& DC. subsp. crispa (Ait.) Turrill - Uncommon; Katahdin (F. Hyland, 1034, 3 August 1938, MAINE); The Owl (A. J. Urban, 22 June 2013, pers. obs.).

Betula cordifolia Regel - Common; Katahdin (G. B. Rossbach, 1298, 4 September 1948, MAINE); North Brother (A. J. Urban, 5 August 2013, pers. obs.); South Brother (A. J. Urban, 5 August 2013, pers. obs.); Mount Coe (G. H. Mittelhauser et al., 27 June 2014, pers. obs.); The Owl (A. J. Urban, 22 June 2013, pers. obs.).

Betula glandulosa Michx. - Rare, S1; Katahdin (G. Thurber, s.n., 25 August 1847, GH).

Betula minor (Tuckerman) Fern. - Rare, S1; Katahdin (M. L. Fernald, s.n., 14 July 1900, NEBC).

BRASSICACEAE

Cardamine bellidifolia L. var. bellidifolia - Rare, S1; Katahdin (M. L. Fernald, s.n., 11 July 1900, NEBC).

CAPRIFOLIACEAE

Diervilla lonicera P. Mill. - Rare; Katahdin (M. L. Fernald, s.n., 14 July 1900, GH).

Linnaea borealis L. subsp. americana (Forbes) Hultén ex Clausen Uncommon; Katahdin (M. L. Fernald, s.n., 13 July 1900, NEBC).

Lonicera villosa (Michx.) J.A. Schultes - Rare; Katahdin (M. L. Fernald, s.n., 13 July 1900, NEBC).

CARYOPHYLLACEAE

Minuartia groenlandica (Retz.) Ostenf. - Uncommon; S3; Katahdin (G. Thurber, s.n., August 1847, NEBC); North Brother (G. H. Mittlehauser et al., 24 June 2014, pers. obs.); Mount Coe (G. H. Mittlehauser et al., 27 June 2014, pers. obs.).

Silene acaulis (L.) Jacq. - Historic (1847), SX; Katahdin (G. Thurber, s.n., August 1847, NEBC).

Stellaria borealis Bigelow subsp. borealis - Historic (1965); Katahdin (F. Steele, s.n., 12 August 1965, NHA).

COMANDRACEAE

Geocaulon lividum (Richards.) Fern. - Rare, S3; Katahdin (Cogbill and Hudson 1990).

CORNACEAE

Chamaepericlymenum canadense (L.) Aschers. \& Graebn. - Occasional; Katahdin (Maine Natural Areas Program, unpubl. data); North Brother (A. J. Urban, 5 August 2013, pers. obs.); South Brother (A. J. Urban, 5 August 2013, pers. obs.); Mount Coe (G. H. Mittelhauser et al., 27 June 2014, pers. obs.); The Owl (A. J. Urban, 22 June 2013, pers. obs.).

CUPRESSACEAE

Juniperus communis L. var. depressa Pursh - Uncommon; Katahdin (M. L. Fernald, s.n., 14 July 1900, NEBC). 


\section{CYPERACEAE}

Carex arctata Boott in Hook. - Uncommon; Katahdin (M. L. Fernald, s.n., 13 July 1900, NEBC).

Carex atrataformis Britt. - Rare, S2S3; Katahdin (M. L. Fernald, s.n., 13 July 1900, NEBC).

Carex bigelowii Torr. ex Schwein. subsp. bigelowii - Uncommon, S2; Katahdin (M. L. Fernald, s.n., 9 July 1900, NEBC); North Brother (G. H. Mittelhauser et al., 24 June 2014, pers. obs.); South Brother (G. H. Mittelhauser et al., 27 June 2014, pers. obs.); Mount Coe (C. D. Richards, 496, 10 June 1955, maine); The Owl (C. V. Cogbill and W. D. Hudson, Jr., unpubl. data).

Carex brunnescens (Pers.) Poir. var. brunnescens - Uncommon; Katahdin (C. B. Graves, s.n., 26 July 1919, NEBC).

Carex communis Bailey var. communis - Historic (1900); Katahdin (1900) (M. L. Fernald, s.n., 14 July 1900, NEBC).

Carex deflexa Hornem. var. deflexa-Uncommon; Katahdin (M. L. Fernald, s.n., 11 July 1900, NEBC).

Carex flava L. - Historic (1900); Katahdin (M. L. Fernald, s.n., 13 July 1900, NEBC).

Carex leptalea Wahlenb. subsp. leptalea - Historic (1900); Katahdin (M. L. Fernald, s.n., 13 July 1900, NEBC).

Carex rariflora (Wahlenb.) Sm. - Historic (1862), sH; Katahdin (G. L. Goodale, s.n., 1862, GH).

Carex scirpoidea Michx. subsp. scirpoidea - Rare, S2; Katahdin (M. L. Fernald, s.n., 11 July 1900, NEBC).

Eriophorum vaginatum L. subsp. spissum (Fern.) Hultén - Uncommon; Katahdin (F. H. Steinmetz, 869, 30 June 1940, MAINE).

Trichophorum alpinum (L.) Pers. - Rare; Katahdin (Maine Natural Areas Program, unpubl. data); South Brother (A. J. Urban, 5 August 2013, pers. obs.).

Trichophorum cespitosum (L.) Hartman subsp. cespitosum - Occasional; Katahdin (G. Thurber, s.n., 25 August 1847, NEBC); North Brother (G. H. Mittelhauser et al., 24 June 2014, pers. obs.); South Brother (C. V. Cogbill and W. D. Hudson, Jr., unpubl. data).

DENNSTAEDTIACEAE

Pteridium aquilinum (L.) Kuhn subsp. latiusculum (Desv.) Hultén - Rare; Katahdin (M. L. Fernald, s.n., 14 July 1900, GH).

DIAPENSIACEAE

Diapensia lapponica L. subsp. lapponica - Common, S2; Katahdin (G. B. Rossbach, 1566, 4 September 1948, MAINE); North Brother (A. J. Urban, 5 August 2013, pers. obs.); South Brother (F. Steele, s.n., 11 August 1965, NHA); The Owl (A. J. Urban, 22 June 2013, pers. obs.).

DROSERACEAE

Drosera rotundifolia L. - Uncommon; Katahdin (M. L. Fernald, s.n., 14 July 1900, NEBC).

DRYOPTERIDACEAE

Dryopteris campyloptera (Kunze) Clarkson - Uncommon; Katahdin (Cogbill and Hudson 1990). 


\section{ERICACEAE}

Andromeda polifolia L. var. glaucophylla (Link) DC. - Historic (1900); Katahdin (Fernald 1901).

Arctous alpina (L.) Nied. - Occasional, S1; Katahdin (M. L. Fernald s.n., 9 July 1900, AAH); North Brother (G. H. Mittelhauser et al., 24 June 2014, pers. obs.).

Empetrum atropurpureum Fern. \& Wieg. - Occasional; Katahdin (G. Thurber, s.n., 25 August 1864, GH); North Brother (G. H. Mittelhauser et al., 24 June 2014, pers. obs.); South Brother (A. J. Urban, 5 August 2013, pers. obs.); Mount Coe (G. H. Mittelhauser et al., 27 June 2014, pers. obs.).

Empetrum nigrum L. - Occasional; Katahdin (G. B. Rossbach, 1572, 4 September 1948, maINE); North Brother (G. H. Mittelhauser et al., 24 June 2014, pers. obs.); South Brother (C. V. Cogbill and W. D. Hudson, Jr., unpubl. data); Mount Coe (C. V. Cogbill and W. D. Hudson, Jr., unpubl. data); The Owl (A. J. Urban, 22 June 2013, pers. obs.).

Gaultheria hispidula (L.) Muhl. ex Bigelow - Uncommon; Katahdin (H. J. Dyer, s.n., 6 October 1940, MAINE); North Brother (G. H. Mittelhauser et al., 24 June 2014, pers. obs.); South Brother (A. J. Urban, 5 August 2013, pers. obs.).

Harrimanella hypnoides (L.) Coville - Rare, S1; Katahdin (S. J. Ewer, s.n., 25 July 1929, NEBC).

Kalmia polifolia Wangenh. - Uncommon; Katahdin (G. Thurber, s.n., August 1847, GH); North Brother (G. H. Mittelhauser et al., 24 June 2014, pers. obs.); South Brother (A. J. Urban, 5 August 2013, pers. obs.).

Kalmia procumbens (L.) Gift, Kron, \& P.F. Stevens ex Galasso, Banfi, \& F. Conti-Uncommon, S1; Katahdin (M. L. Fernald, s.n., 9 July 1900, NEBC).

Phyllodoce caerulea (L.) Bab. - Rare, S1; Katahdin (M. L. Fernald, s.n., 9 July 1900, NEBC).

Rhododendron groenlandicum (Oeder) Kron \& Judd - Common; Katahdin (H. A. Allard, 5144, 4 July 1938, GH); North Brother (A. J. Urban, 5 August 2013, pers. obs.); South Brother (A. J. Urban, 5 August 2013, pers. obs.); Mount Coe (G. H. Mittelhauser et al., 27 June 2014, pers. obs.); The Owl (A. J. Urban, 22 June 2013, pers. obs.).

Rhododendron lapponicum (L.) Wahlenb. - Uncommon, S1; Katahdin (G. Thurber, s.n., August 1847, NEBC).

Vaccinium angustifolium Ait. - Occasional; Katahdin (F. H. Steinmetz, s.n., September 1930, MAINE); North Brother (A. J. Urban, 5 August 2013, pers. obs.); South Brother (A. J. Urban, 5 August 2013, pers. obs.); Mount Coe (G. H. Mittelhauser et al., 27 June 2014, pers. obs.); The Owl (A. J. Urban, 22 June 2013, pers. obs.).

Vaccinium boreale Hall \& Aalders - Rare, S2; Katahdin (J. Hoekwater, s.n., 2 September 1994, MAINE); North Brother (G. H. Mittelhauser et al., 24 June 2014, pers. obs.).

Vaccinium cespitosum Michx. - Uncommon; Katahdin (M. L. Fernald, s.n., 9 July 1900, NEBC).

Vaccinium myrtilloides Michx. - Rare; Katahdin (C. D. Richards and G. R. Cooper, 349, 8 July 1954, MAINE); North Brother (G. H. Mittelhauser et al., 24 June 2014, pers. obs.); South Brother (A. J. Urban, 5 August 2013, 
pers. obs.); Mount Coe (G. H. Mittelhauser et al., 27 June 2014, pers. obs.); The Owl (C. V. Cogbill and W. D. Hudson, Jr., unpubl. data).

Vaccinium uliginosum L. - Common; Katahdin (G. Thurber, s.n., 25 August 1847, GH); North Brother (A. J. Urban, 5 August 2013, pers. obs.); South Brother (A. J. Urban, 5 August 2013, pers. obs.); Mount Coe (G. H. Mittelhauser et al., 27 June 2014, pers. obs.); The Owl (A. J. Urban, 22 June 2013, pers. obs.).

Vaccinium vitis-idaea L. subsp. minus (Lodd.) Hultén - Occasional; Katahdin (M. L. Fernald, s.n., 8 July 1900, NEBC); North Brother (A. J. Urban, 5 August 2013, pers. obs.); South Brother (A. J. Urban, 5 August 2013, pers. obs.); Mount Coe (G. H. Mittelhauser et al., 27 June 2014, pers. obs.); The Owl (A. J. Urban, 22 June 2013, pers. obs.).

\section{HUPERZIACEAE}

Huperzia $\times$ josephbeitelii A. Haines - Uncommon; Katahdin (M. L. Fernald, s.n., 11 July 1900, GH).

Huperzia appressa (Desv.) A. \& D. Löve - Uncommon, S2; Katahdin (G. B. Rossbach, 6726, 22 July 1967, MAINE); South Brother (C. V. Cogbill and W. D. Hudson, Jr., unpubl. data).

JUNCACEAE

Juncus trifidus L. - Common; Katahdin (G. B. Rossbach, 6731, 22 June 1967, MAINE); North Brother (A. J. Urban, 5 August 2013, pers. obs.); South Brother (A. J. Urban, 5 August 2013, pers. obs.); Mount Coe (G. H. Mittelhauser et al., 27 June 2014, pers. obs.); The Owl (A. J. Urban, 22 June 2013, pers. obs.).

Luzula confusa Lindeberg - Rare, S1; Katahdin (M. L. Fernald, s.n., 11 July 1900, GH).

Luzula parviflora (Ehrh.) Desv. subsp. melanocarpa (Michx.) Hämet-Ahti Rare; Katahdin (M. L. Fernald, s.n., 9 July 1900, GH).

Luzula spicata (L.) DC. - Rare, S1; Katahdin (A. H. Norton, 16428, 29 August 1924, NHA).

LILIACEAE

Clintonia borealis (Ait.) Raf. - Rare; Katahdin (A. H. Norton, 17180, 10 August 1926, NHA).

Streptopus ×oreopolis Fern. - Rare; Katahdin (G. L. Stebbins, Jr., 426, 15 August 1928, GH).

Streptopus amplexifolius (L.) DC. -Rare; Katahdin (Maine Natural Areas Program, unpubl. data).

Streptopus lanceolatus (Ait.) Reveal - Rare; Katahdin (S. J. Ewer, s.n., 1 August 1929, NEBC).

\section{LYCOPODIACEAE}

Diphasiastrum sitchense (Rupr.) Holub - Rare, S1; Katahdin (M. L. Fernald, s.n., 9 July 1900, GH).

Lycopodium lagopus (Laestad. ex Hartm.) Zinserl. ex Kuzen. - Historic (1929); Katahdin (M. L. Fernald, s.n., 14 July 1900, NEBC).

Spinulum annotinum (L.) A. Haines - Rare; Katahdin (G. B. Rossbach, 6727, 22 July 1967, MAINE).

Spinulum canadense (Ness.) A. Haines - Uncommon; Katahdin (C. D. Richards, 293, 10 September 1953, MAINE); North Brother (G. H. Mittelhauser et al., 24 June 2014, pers. obs.). 


\section{MELANTHIACEAE}

Trillium undulatum Willd. - Rare; Katahdin (Fernald 1901).

\section{MYRSINACEAE}

Lysimachia borealis (Raf.) U. Manns \& A. Anderb. - Rare; Katahdin (Cobgill and Hudson 1990).

ONAGRACEAE

Epilobium anagallidifolium Lam. - Rare, S1; Katahdin (M. L. Fernald, s.n., 9 July 1900, NEBC).

Epilobium hornemannii Reichenb. subsp. hornemannii - Rare, S1; Katahdin (C. B. Graves, s.n., 27 July 1919, NEBC).

Epilobium lactiflorum Hausskn. - Historic (1929), SH; Katahdin (S. J. Ewer, s.n., 24 July 1929, NEBC).

\section{ORCHIDACEAE}

Neottia cordata (L.) Rich. - Historic (1874); Katahdin (Lamson-Scribner 1892).

Platanthera dilatata (Pursh) Lindl. ex Beck var. dilatata - Historic (1934); Katahdin (Fernald 1901).

OROBANCHACEAE

Castilleja septentrionalis Lindl. - Rare, S3; Katahdin (M. L Fernald, s.n., 13 July 1900, NEBC).

Euphrasia oakesii Wettst. - Historic (1900), sH; Katahdin (Fernald 1901).

Rhinanthus minor L. subsp. groenlandicus (Ostenf.) L. Neum. - Historic (1902); Katahdin (Harvey 1903).

OSMUNDACEAE

Osmunda claytoniana L. - Historic (1900); Katahdin (M. L. Fernald, s.n., 14 July 1900, NEBC).

OXALIDACEAE

Oxalis montana Raf. - Rare; Katahdin (Cogbill and Hudson 1990). PINACEAE

Abies balsamea (L.) P. Mill. - Common; Katahdin (M. L. Fernald, s.n., 12 July 1900, NEBC ); North Brother (A. J. Urban, 5 August 2013, pers. obs.); South Brother (A. J. Urban, 5 August 2013, pers. obs.); Mount Coe (G. H. Mittelhauser et al., 27 June 2014, pers. obs.); The Owl (A. J. Urban, 22 June 2013, pers. obs.).

Picea glauca (Moench) Voss -Historic (1926); Katahdin (A. H. Norton, 17161, 10 August 1926, NHA).

Picea mariana (P. Mill.) B.S.P. - Common; Katahdin (F. H. Steinmetz, 1756, 14 June 1939, MAINE); North Brother (A. J. Urban, 5 August 2013, pers. obs.); South Brother (A. J. Urban, 5 August 2013, pers. obs.); Mount Coe (G. H. Mittelhauser et al., 27 June 2014, pers. obs.); The Owl (A. J Urban, 22 June 2013, pers. obs.).

POACEAE

Agrostis mertensii Trin. - Occasional, S2; Katahdin (M. L. Fernald, s.n., 11 July 1900, NeBC); Mount Coe (C. V. Cogbill and W. D. Hudson, Jr., unpubl. data); The Owl (Maine Natural Areas Program, unpubl. data).

Anthoxanthum monticola (Bigelow) Y. Schouten \& Veldkamp subsp. monticola - Rare, S1; Katahdin (A. Young, Jr., s.n., August 1847, GH); The Owl (Maine Natural Areas Program, unpubl. data). 
Calamagrostis canadensis (Michx.) Beauv. var. canadensis - Uncommon; Katahdin (C. B. Graves, s.n., 27 July 1919, NEBC).

Calamagrostis pickeringii Gray - Historic (1928), S1; Katahdin (G. L. Stebbins, Jr., s.n., 15 August 1928, GRCH).

Calamagrostis stricta (Timm) Koel. subsp. inexpansa (Gray) C. W. Greene Rare, S1; Katahdin (Maine Natural Areas Program, unpubl. data).

Cinna latifolia (Trev. ex Goepp.) Griseb. - Historic (1900); Katahdin (Fernald 1901).

Danthonia spicata (L.) Beauv. ex Roemer \& J. A. Schultes - Historic (1929); Katahdin (M. L. Fernald, s.n., 14 July 1900, GH).

Deschampsia flexuosa (L.) Trin. - Uncommon; Katahdin (G. B. Rossbach, 6723b, 22 July 1967, MAINE).

Festuca prolifera (Piper) Fern. - Rare, S1; Katahdin (Fernald 1901).

Phleum alpinum L. - Rare, S2; Katahdin (Fernald 1901).

Poa laxa Haenke subsp. fernaldiana (Nannf.) N. Hylander - Rare, S1;

Katahdin (A. Young, Jr., s.n., August 1847, GH).

Schizachne purpurascens (Torr.) Swallen - Rare; Katahdin (Fernald 1901).

Trisetum spicatum (L.) Richter - Historic (1969); Katahdin (Fernald 1901).

Vahlodea atropurpurea (Wahlenb.) Fries ex Hartman - Rare, S1; Katahdin (Fernald 1901).

POLYGONACEAE

Bistorta vivipara (L.) Delarbre - Rare, S1; Katahdin (M. L. Fernald, s.n., 11 July 1900, NEBC).

RANUNCULACEAE

Coptis trifolia (L.) Salisb. - Uncommon; Katahdin (S. J. Ewer, s.n., 18 July 1929, NEBC).

ROSACEAE

Dasiphora floribunda Raf. - Rare; Katahdin (Fernald 1901).

Fragaria virginiana Duchesne subsp. virginiana - Historic (1900); Katahdin (Fernald 1901).

Prunus pensylvanica L. f. var. pensylvanica - Rare; Katahdin (M. L. Fernald, s.n., 13 July 1900, NEBC).

Prunus virginiana L. var. virginiana - Rare; Katahdin (M. L. Fernald, s.n., 13 July 1900, NEBC).

Rubus pubescens Raf. - Rare; Katahdin (S. J. Ewer, s.n., 24 July 1929, NEBC). Sibbaldiopsis tridentata (Ait.) Paulé \& Soják - Occasional; Katahdin (G. B. Rossbach, 6723a, 22 July 1967, MAINE); South Brother (C. V. Cogbill and W. D. Hudson, Jr., unpubl. data); Mount Coe (G. H. Mittelhauer et al., 27 June 2014, pers. obs.); The Owl (A. J. Urban, 22 June 2013, pers. obs.).

Sorbus americana Marsh. - Uncommon; Katahdin (M. L. Fernald, s.n., 14 July 1900, NEBC).

Sorbus decora (Sarg.) Schneid. - Uncommon; Katahdin (Fernald 1901); North Brother (A. J. Urban, 5 August 2013, pers. obs.); The Owl (A. J. Urban, 22 June 2013, pers. obs.).

Spiraea alba Du Roi var. latifolia (Ait.) Dippel - Uncommon; Katahdin (Fernald 1901).

RUBIACEAE

Galium kamtschaticum Steller ex J. A. \& J. H. Schultes - Historic (1900), S2; Katahdin (M. L. Fernald, s.n., 13 July 1900, NEBC). 


\section{RUSCACEAE}

Maianthemum canadense Desf. - Rare; Katahdin (Cogbill and Hudson 1990); The Owl (A. J. Urban, 22 June 2013, pers. obs.).

Maianthemum racemosum (L.) Link subsp. racemosum - Historic (1900); Katahdin (M. L. Fernald, s.n., 14 July 1900, GH).

\section{SALICACEAE}

Salix arctophila Cockerell ex Heller - Rare, S1; Katahdin (Maine Natural Areas Program, unpubl. data).

Salix argyrocarpa Anderss. - Historic (1934), SH; Katahdin (S. J. Ewer, s.n., 3 August 1929, NEBC).

Salix herbacea L. - Uncommon, S1; Katahdin (C. B. Graves, s.n., 27 July 1919, NEBC).

Salix planifolia Pursh subsp. planifolia - Rare, S1; Katahdin (J. R. Churchill, s.n., 9 July 1900, NHA).

Salix uva-ursi Pursh - Occasional, S1; Katahdin (M. L. Fernald, s.n., 9 July 1900, NEBC).

SAXIFRAGACEAE

Micranthes foliolosa (R. Br.) Gornall - Rare, S1; Katahdin (M. L. Fernald, s.n., 11 July 1900, NEBC).

Saxifraga paniculata P. Mill. subsp. neogaea (Butters) D. Löve - Historic (1975), S1; Katahdin (W. D. Hudson, Jr., s.n., 22 September 1975, MAINE). THELYPTERIDACEAE

Phegopteris connectilis (Michx.) Watt - Rare; Katahdin (A. H. Norton, 17160, 9 August 1926, NHA).

\section{VIOLACEAE}

Viola blanda Willd. var. palustriformis Gray - Rare; Katahdin (M. L. Fernald, s.n., 14 July 1900, NEBC).

Viola labradorica Schrank - Rare; Katahdin (M. L. Fernald, s.n., 14 July 1900, GH).

Viola palustris L. var. palustris - Historic (1900); Katahdin (J. R. Churchill, s.n., 9 July 1900, NEBC). The identification of this voucher cannot be confirmed as flower color was not noted on the specimen and fruit characters are needed to confirm identification. Other vouchers originally identified as this species, from lower elevations on Katahdin, noted white flower color on the herbarium label and have all been annotated to Viola pallens. See Haines (2011) for further discussion.

Viola selkirkii Pursh ex Goldie - Historic (1900); Katahdin (M. L. Fernald, s.n., 13 July 1900, NEBC). 
Copyright of Rhodora is the property of Allen Press Publishing Services Inc. and its content may not be copied or emailed to multiple sites or posted to a listserv without the copyright holder's express written permission. However, users may print, download, or email articles for individual use. 